\title{
Déficit, poupança e crescimento ${ }^{\dagger}$
}

Luiz Carlos Bresser-Pereira*

RESUMO - A política de crescimento com poupança externa provoca no curto prazo aumento a uma alta taxa de substituição da poupança interna pela externa. No médio prazo, continuando o país a incorrer em déficits em conta corrente, sobrevém uma crise de balanço de pagamentos que anula os parcos efeitos positivos trazidos pelo pequeno aumento do investimento nos anos de alto déficit em conta corrente. Sem dúvida, é preciso aumentar o investimento e a poupança. Mas não é adotando uma política de déficit em conta corrente e de taxa de câmbio apreciada que se estimulará a poupança privada.

Em sua tréplica, o Prof. Affonso Celso Pastore procurou responder minha crítica à tese aceita convencionalmente (não apenas por economistas ortodoxos) segundo a qual o Brasil precisa de poupança externa, ou seja, de déficits em conta corrente, para crescer. Afinal, ele se concentrou em um ponto: em demonstrar não ser verdade a tese que todo o aumento da poupança externa se transformaria em consumo, de forma que uma política de crescimento com poupança externa não provocaria qualquer aumento do investimento. Definida assim minha tese, ele em seguida apresentou um gráfico de dispersão correlacionando déficit em conta corrente com taxa de investimento, ambos em relação ao PIB. O resultado é uma linha próxima de 135 graus $(45 \%+90 \%)$ com um grau de dispersão pequeno; ficaria, assim, "demonstrado" meu erro.

Em meu modelo não existe essa ideia extrema, e sim a tese de que uma boa parte da poupança externa recebida pelo país se transforma em consumo, verificando-se uma alta taxa de substituição da poupança interna pela externa. Minha crítica é a algo geralmente aceito como pressuposto de que a poupança externa é um complemento à poupança interna, e, portanto, que haveria uma quase perfeita transferência da poupança externa para o investimento: que cada dólar que ingressa no país como poupança externa se transformaria em aumento do investimento. Rejeito, portanto, o pressuposto de que a taxa de substituição da poupança interna pela externa esteja próximo de zero.

O que realmente acontece quando essa política é adotada é o aumento artificial dos salários e, dada uma alta propensão a consumir, temos o aumento do consumo e uma elevada taxa de substituição da poupança interna pela externa. Em alguns casos, como no período

\footnotetext{
† Escrito para o jornal O Estado de S. Paulo para publicação em 21 de março, mas o jornal preferiu não alimentar o debate. Publicado em http://www.bresserpereira.org.br.

* Doutor em economia pela Universidade de São Paulo. Professor da FGV-SP e ex-Ministro da Fazenda.
} 
1994-1999, ela pode ser muito alta: a poupança externa aumentou em cerca de 4 pontos percentuais do PIB enquanto a taxa de investimento permaneceu estável em torno de 17\%. A taxa de substituição ficou próxima a 100\% mas, na maioria dos casos, situa-se em torno de 50\%.

A substituição da poupança interna pela externa, porém, só ocorre quando a taxa de câmbio é uma taxa de mercado. Pastore ignora esse fato e constrói seu gráfico de dispersão com dados desde 1970. Isto não faz sentido. Quando a entrada de capitais não aprecia o câmbio porque este está controlado, não existe apreciação causada pela política de crescimento com poupança externa, e não há porquê se falar em substituição. No Brasil, a taxa de câmbio só começou a ser determinada pelo mercado em 1992 em razão da abertura comercial e financeira, e só se tornou plenamente por ele determinada pelo mercado a partir de 1999, com a flutuação do real. Fiz, portanto, o mesmo gráfico de dispersão, mas com dados limitados a 1992-2009. O resultado mostra também uma correlação entre as duas variáveis, mas como o leitor poderá ver comparando os dois gráficos, a linha de tendência no período 1992-2009 é muito menos acentuada do que a linha do gráfico de Pastore. Isto demonstra que um aumento na poupança externa causa um aumento pequeno na taxa de investimento, confirmando minha tese. Um segundo gráfico com uma defasagem de um ano (porque os investimentos demoram a reagir ao câmbio) torna a substituição da poupança interna pela externa ainda mais clara porque a linha de tendência é ainda menos inclinada, mas o primeiro gráfico é suficiente para demonstrar a tese.

GRÁFICO 1 - TAXA DE INVESTIMENTO X SALDO EM TRANSAÇÕES CORRENTES (EM \% PIB). VALORES PARA O PERÍODO ENTRE 1992 E 2009

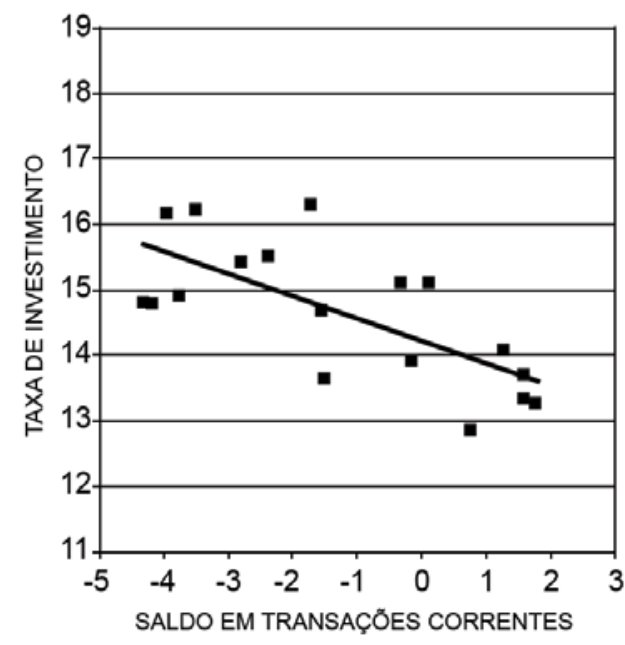

O que significa uma taxa de substituição elevada? Significa ineficiência da política de crescimento com poupança externa. Suponhamos, por exemplo, que em determinado país 
essa taxa está em torno de 50\%. Nesse país, um investidor estrangeiro faz um investimento direto de 100, obtém um retorno de 20 e remete esse lucro para o exterior, restando 100 de dívida patrimonial do país. O investidor estará realizando um retorno de $20 \%$, mas a taxa de remessa de lucros sobre a dívida patrimonial (a taxa paga pelo país em troca do investimento) será equivalente a $40 \%$ do investimento efetuado, já que $50 \%$ do valor originalmente entrado no país acabou no consumo em diminuição da poupança interna via apreciação do câmbio. Se a taxa de substituição for de $80 \%$, a ineficiência da poupança externa será ainda maior: o investidor continuará ganhando seus $20 \%$, mas o país estará pagando $100 \%$ !

GRÁFICO 2 - TAXA DE INVESTIMENTO (DEFASADA EM UM PERÍODO) X SALDO EM TRANSAÇÕES CORRENTES (EM \% PIB). VALORES PARA O PERÍODO ENTRE 1992 E 2009



Em síntese, a política de crescimento com poupança externa provoca no curto prazo aumento a uma alta taxa de substituição da poupança interna pela externa. No médio prazo, continuando o país a incorrer em déficits em conta corrente, sobrevém uma crise de balanço de pagamentos que anula os parcos efeitos positivos trazidos pelo pequeno aumento do investimento nos anos de alto déficit em conta corrente. Sem dúvida, é preciso aumentar o investimento e a poupança. Mas não é adotando uma política de déficit em conta corrente e de taxa de câmbio apreciada que se estimulará a poupança privada. Quanto à poupança pública, não basta reduzir a despesa corrente; é necessário, adicionalmente, nos termos da Reforma Gerencial de 1995, tornar mais eficientes os serviços sociais e científicos do Estado. 
